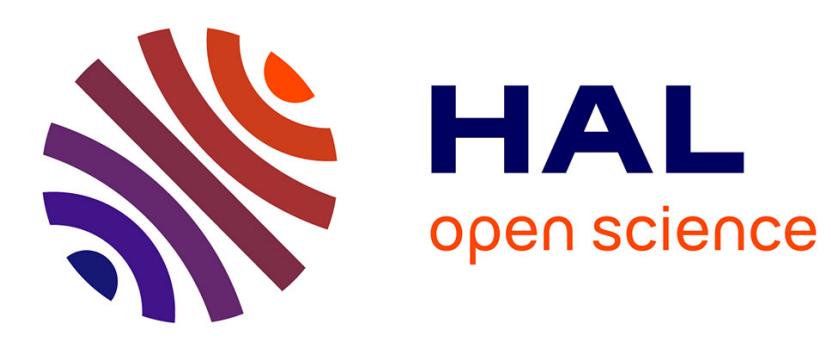

\title{
Effects of olanzapine on glucose transport, proliferation and survival in $\mathrm{C} 2 \mathrm{C} 12$ myoblasts
}

Giovanni Tulipano, Pierfranco Spano, Daniela Cocchi

\section{To cite this version:}

Giovanni Tulipano, Pierfranco Spano, Daniela Cocchi. Effects of olanzapine on glucose transport, proliferation and survival in $\mathrm{C} 2 \mathrm{C} 12$ myoblasts. Molecular and Cellular Endocrinology, 2008, 292 (1-2), pp.42. 10.1016/j.mce.2008.04.010 . hal-00532021

\section{HAL Id: hal-00532021 \\ https://hal.science/hal-00532021}

Submitted on 4 Nov 2010

HAL is a multi-disciplinary open access archive for the deposit and dissemination of scientific research documents, whether they are published or not. The documents may come from teaching and research institutions in France or abroad, or from public or private research centers.
L'archive ouverte pluridisciplinaire HAL, est destinée au dépôt et à la diffusion de documents scientifiques de niveau recherche, publiés ou non, émanant des établissements d'enseignement et de recherche français ou étrangers, des laboratoires publics ou privés. 


\section{Accepted Manuscript}

Title: Effects of olanzapine on glucose transport, proliferation and survival in $\mathrm{C} 2 \mathrm{C} 12$ myoblasts

Authors: Giovanni Tulipano, PierFranco Spano, Daniela Cocchi

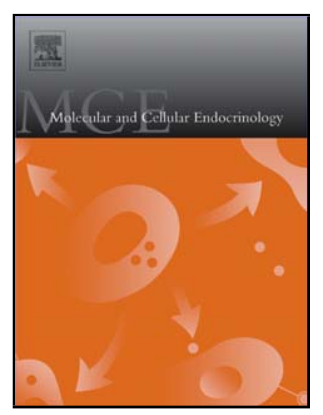

PII:

S0303-7207(08)00152-4

DOI: doi:10.1016/j.mce.2008.04.010

Reference: MCE 6865

To appear in: $\quad$ Molecular and Cellular Endocrinology

Received date: $\quad$ 17-3-2008

Revised date: $\quad 14-4-2008$

Accepted date: $\quad 15-4-2008$

Please cite this article as: Tulipano, G., Spano, P.F., Cocchi, D., Effects of olanzapine on glucose transport, proliferation and survival in $\mathrm{C} 2 \mathrm{C} 12$ myoblasts, Molecular and Cellular Endocrinology (2007), doi:10.1016/j.mce.2008.04.010

This is a PDF file of an unedited manuscript that has been accepted for publication. As a service to our customers we are providing this early version of the manuscript. The manuscript will undergo copyediting, typesetting, and review of the resulting proof before it is published in its final form. Please note that during the production process errors may be discovered which could affect the content, and all legal disclaimers that apply to the journal pertain. 
EFFECTS OF OLANZAPINE ON GLUCOSE TRANSPORT, PROLIFERATION AND SURVIVAL IN C2C12 MYOBLASTS

Running title: olanzapine and response to insulin

Giovanni Tulipano, PierFranco Spano, Daniela Cocchi

Divisions of Pharmacology and Toxicology, Department of Biomedical Sciences and

Biotechnologies, University of Brescia, Brescia, Italy

Keywords: atypical antipsychotics, metabolic effects, skeletal muscle cells, glucose uptake, DNA laddering

Address correspondance to:

Giovanni Tulipano

Division of Pharmacology

Dept. Biomedical Sciences and Biotechnologies

University of Brescia (Italy)

Phone 00390303717510

Fax 00390303717529

tulipano@med.unibs.it 


\begin{abstract}
The aim of our study was to investigate the direct effects of atypical antipsychotics on muscle cell functions in order to ascertain the diabetic liability of these drugs. We investigated the effects of olanzapine, clozapine and $\alpha$-methyl-5-hydroxytryptamine on basal glucose uptake and glucose uptake in response to insulin using in vitro cultures of mouse skeletal muscle satellite cells (C2C12). We extended our study to the effects of these compounds on cell proliferation, survival and differentiation into myotubes and on the growth of differentiated myotubes. Olanzapine and $\alpha$ methyl-5-HT stimulated 2-deoxyglucose uptake in C2C12 myoblasts in a dose-dependent manner (minimal effective dose: $2 \mu \mathrm{M}$ olanzapine and $10 \mu \mathrm{M} \alpha$-methyl-5-HT). The treatment with clozapine had no effect on glucose transport. Insulin and olanzapine increased the plasma membrane abundance of glucose transporter GLUT4. We investigated whether protein kinase Akt (PKB) and AMP-dependent kinase may partecipate in mediating olanzapine effects on glucose transport. Clozapine and olanzapine did not induce DNA laddering in differentiating myoblasts and differentiated myotubes and did not affect myotube growth. Olanzapine-induced glucose disposal in vitro is consistent with the acute lowering of plasma glucose/insulin concentrations that occurs in rats before olanzapine-induced overeating (Albaugh et al., 2006).
\end{abstract}




\section{INTRODUCTION}

Atypical antipsychotics are an effective therapy for schizophrenia and generally appear to be better tolerated than conventional agents. However, concerns have been raised about the adverse effects of some atypical antipsychotic drugs on metabolic functions. Body weight gain and hyperlipidemia are frequently observed during treatment with olanzapine or clozapine. These drugs are also suspected of inducing insulin resistance and new-onset diabetes, even in the absence of weight gain or shortly after the beginning of treatment (Henderson et al., 2002; Holt et al., 2004; Melkersson et al, 2004; Mir et al., 2001; Ryan et al., 2003; Sowell et al., 2003).

Olanzapine and clozapine block multiple neurotransmitter receptors with affinities varying two orders of magnitude (Kapur et al., 2003). A number of studies have investigated the effects of atypical antipsychotics on food intake and weight gain in rodents in order to develop an animal model of antipsychotics-induced obesity and insulin resistance (Baptista et al., 1993, Fadel et al., 2002; Kaur et al., 2002; Lee et al., 2002; Pouzet et al., 2003). Remarkably, unlike humans, differences between clozapine- and olanzapine-induced effects have been reported in rats. Chronically, olanzapine, but not clozapine, increased food intake and body weight (Arjona et al., 2004). Acutely, both drugs impaired whole-body insulin sensitivity and clozapine administration caused mild hyperglycemia (Houseknecht et al, 2007; Tulipano et al., 2007). Olanzapine, but not clozapine, reduced basal plasma glucose and leptin concentrations when lower doses of the drugs were used (Albaugh et al., 2006). Based on the latter result, olanzapine-induced weight gain may be secondary to hyperphagia associated with acute lowering of plasma glucose and leptin, in rodents.

Recent studies have examined whether atypical antipsychotics exert direct effects at the level of insulin target tissues such as white adipose tissue and skeletal muscle. In 3T3-L1 adipocytes and primary cultured rat adipocytes, olanzapine did not affect basal or insulin stimulated glucose transport at doses 0.1-0.4 $\mu \mathrm{M}$ (Robinson et al., 2006). However, an increase in glucose uptake in response to $100 \mu \mathrm{M}$ olanzapine has been shown using the same cells (Houseknecht et al., 2007). Clozapine reduced insulin-stimulated glucose transport in adipocytes, starting at $5 \mu \mathrm{M}$ dose. Both 
drugs altered lipogenesis and lipolysis in favor of progressive lipid accumulation and adipocyte enlargement (Vestri et al., 2007; Minet-Ringuet et al., 2007). Studies on glucose transport into isolated rat epitrochlearis skeletal muscle did not evidence any effect of clozapine (Houseknecht et al., 2007). Conversely, a significant increase of glucose uptake into isolated muscles from rats treated with olanzapine in vivo and subsequently incubated with $10 \mu \mathrm{M}$ olanzapine in vitro, was shown (Houseknecht et al., 2007). In murine skeletal muscle cell (C2C12) cultures, clozapine did not inhibit basal and insulin-induced glucose transport but it was able to antagonize the stimulatory effect of $\alpha$-methyl-5-hydroxytryptamine, a 5- $\mathrm{HT}_{2 \mathrm{~A}}$ agonist, on glucose uptake (Tulipano et al., 2007). Finally, $100 \mu \mathrm{M}$ olanzapine impaired glycogen synthesis via inhibition of the classical insulin-signaling cascade in L6 skeletal muscle cells; the effect of olanzapine on glucose internalization was not studied in these cells (Engl et al., 2005).

In humans, skeletal muscle accounts for more than $75 \%$ of insulin-dependent glucose disposal. The aim of our study was to further investigate the direct effects of atypical antipsychotics on muscle cell functions in order to ascertain the diabetic liability of these drugs. We investigated the effects of olanzapine, as compared with clozapine, on basal glucose uptake and glucose uptake in response to insulin using in vitro cultures of mouse myoblast cells $(\mathrm{C} 2 \mathrm{C} 12)$. The $\mathrm{C} 2 \mathrm{C} 12$ cell line differentiates rapidly, forming contractile myotubes and producing characteristic muscle proteins. The use of $\mathrm{C} 2 \mathrm{C} 12$ cells allowed us to extend our study to the effects of olanzapine on cell proliferation, survival and differentiation into myotubes and on the growth of differentiated myotubes. 


\section{MATERIALS AND METHODS}

Cell culture. Mouse myoblasts cells (C2C12 cell line, ATCC number CRL-1772) and human rabdomyosarcoma cells (RD) were grown in Dulbecco's Modified Eagle Medium (DMEM 4.5 g/L glucose, Sigma), supplemented with $10 \%$ FCS and antibiotics $(100 \mathrm{u} / \mathrm{ml}$ penicillin/ $100 \mu \mathrm{g} / \mathrm{ml}$ streptomycin). Cells were maintained at subconfluent conditions, in a humified incubator at $37^{\circ} \mathrm{C}$, with ambient oxygen and $5 \% \mathrm{CO}_{2}$.

C2C12 cell differentiation. Cells were seeded onto 24-well culture dishes and then allowed to grow to confluency in DMEM with FCS and differentiated in DMEM supplemented with 2\% horse serum (HS). Cells were maintained for 3-5 days to obtain polynucleated myotubes. The growth medium was changed every day.

2-deoxyglucose uptake. Cells were seeded onto 24-well culture dishes (80000 cells/well) and allowed to grow to confluency in DMEM supplemented with FCS. Before the experiment, confluent myoblasts were serum-starved for $24 \mathrm{~h}$ and then pre-incubated with physiological buffered salt solution (Dulbecco's phosphate buffered saline, DPBS, with $\mathrm{CaCl}_{2}$ and $\mathrm{MgCl}_{2}$ ) for 2 h. Cells were then incubated in DPBS in the presence or in the absence of $100 \mathrm{nM}$ insulin (Sigma) for $30 \mathrm{~min}$. To start the glucose uptake, $100 \mu \mathrm{l}$ DPBS containing $0.5 \mu \mathrm{Ci}$ 2-deoxy-D- $\left[{ }^{3} \mathrm{H}\right]$ glucose $(60 \mu \mathrm{Ci} /$ nmoles; MP Biomedicals, Irvine, CA, USA) and 500 nmoles 2-deoxy-D-glucose or, alternatively, D-glucose (both products from Sigma) were added to each well; 5 min later, dishes were placed on ice, the buffer was removed and cells were washed four times with ice-cold PBS and dissolved in distilled water containing $2 \% \operatorname{SDS}\left(30 \mathrm{~min}, 37^{\circ} \mathrm{C}\right)$. Incorporated radioactivity was measured in a liquid scintillation counter (Wallac, Turku, Finland) using UltimaGold (Beckman) as LSC cocktail. The results were corrected for non-specific uptake background by subtracting the counts obtained with $10 \mu \mathrm{M}$ cytochalasin B (Sigma). Olanzapine (Eli Lilly, Indianapolis, USA) was dissolved in dimethylsulfoxide (DMSO) and added to the pre-incubation media (DMEM without FCS or DPBS) at different times (16-h, 2-h, $30 \mathrm{~min})$ before the uptake assay. The final DMSO concentration was adjusted to $0.1 \%$ in each well. $\alpha$-Methyl-5-hydroxytryptamine ( $\alpha$-methyl-5-HT; 
Tocris, Bristol, UK) was dissolved in water. Clozapine (Tocris) was dissolved in DMSO. 5aminoimidazolo-4-carboxyamide ribonucleoside (AICAR, $250 \mathrm{mM}$ solution in water) was purchased from Cell Signaling Technology (Danvers, MA).

Western blot analysis of Akt- and AMPK phosphorylation and GLUT4 translocation to plasmamembrane. Cells were seeded onto $10-\mathrm{cm}$ culture plates and allowed to grow to confluency. Before the experiment, confluent myoblasts were serum-starved for $24 \mathrm{~h}$ and then pre-incubated with DPBS for $2 \mathrm{~h}$ in the presence or in the absence of $20 \mu \mathrm{M}$ olanzapine. Insulin was added to the incubation media $30 \mathrm{~min}$ before harvesting the cells.

To assess the levels of phospho-ser ${ }^{473}$-Akt, cells were washed with PBS and scraped into $1 \mathrm{ml}$ of radioimmune precipitation buffer (RIPA buffer: $50 \mathrm{mM}$ Tris- $\mathrm{HCl}, \mathrm{pH}$ 7.4, $150 \mathrm{mM} \mathrm{NaCl}, 5 \mathrm{mM}$ EDTA, $10 \mathrm{mM} \mathrm{NaF}, 1 \%$ Nonidet P-40, 0.5\% sodium deoxycholate, $0.1 \%$ SDS, $5 \mathrm{mM}$ sodium fluoride and $1 \mathrm{mM}$ sodium orthovanadate and a mixture of protease inhibitors). Cell lysates were centrifuged at $20000 \mathrm{~g}$ for $30 \mathrm{~min}$ at $4^{\circ} \mathrm{C}$ and the resulting supernatants were subjected to Western blotting. Briefly, equal amounts $(70 \mu \mathrm{g})$ of proteins were separated by SDS-PAGE and then transferred to a nitrocellulose membrane. Membranes were blocked in 5\% nonfat milk in TBSTween $\left(0.1 \%\right.$ Tween-20) before overnight incubation with primary antibody at $4{ }^{\circ} \mathrm{C}$. Membranes were then washed in TBS-Tween and incubated with HRP-coniugated secondary antibodies (Santa Cruz) for $1 \mathrm{~h}$ at room temperature. Protein bands were detected using enhanced chemioluminescent reagents (Chemicon). Gel-Pro analyzer 3.1 software was used to quantify protein bands detected on western blots.

To assess GLUT4 translocation to plasmamembrane (PM) from an insulin-responsive vesicular compartment, cells were subjected to subcellular fractionation. Briefly, cells were washed with icecold PBS, harvested and homogenized with a Polytron homogenizer in $5 \mathrm{mM}$ Tris- $\mathrm{HCl}$ containing 2 $\mathrm{mM}$ EDTA and a mixture of protease inhibitors ( $\mathrm{pH} 7.8)$ and centrifuged at $80 \mathrm{~g}$ for $10 \mathrm{~min}$ to pellet unbroken cells and nuclei. The supernatant was centrifuged at $20000 \mathrm{~g}$ for $40 \mathrm{~min}$ at $4^{\circ} \mathrm{C}$ and the resulting pellet was resuspended in $50 \mathrm{mM}$ Tris- $\mathrm{HCl}$ containing $5 \mathrm{mM} \mathrm{MgCl} 2,1 \mathrm{mM}$ EGTA and the 
protease inhibitors ( $\mathrm{pH} 7.8$ ), layered on a 35\% sucrose cushion, and centrifuged at $150000 \mathrm{~g}$ for 90 min to separate the light vesicular and heavy membrane fractions as described by Lamey et al. The heavy fraction, at the bottom of the sucrose cushion was resuspended in RIPA buffer. Glycosylated proteins were partially enriched using Concanavalin-A-sepharose beads (ConA sepharose, GE Healthcare). Proteins were eluted from the beads using SDS-sample buffer for $20 \mathrm{~min}$ at $60{ }^{\circ} \mathrm{C}$ and then resolved on $10 \%$ SDS-polyacrylamide gels. Western blot analysis was performed as described above.

To assess the levels of phospho-thr ${ }^{172}$-AMPK $\alpha$, confluent cells were switched to the differentiating medium containing $2 \%$ HS and maintained for 5 days to obtain polynucleated myotubes. Before the experiment, myotubes were serum-starved overnight and then pre-incubated with fresh medium without serum for 2 hours. Myotubes were treated with $1 \mathrm{mM}$ AICAR for 30 min (Smith et al., 2005). Additional myotubes were incubated with either vehicle or $20 \mu \mathrm{M}$ olanzapine for 30 - or 120 min. Cell lysis and western blot analysis of cell lysates were performed as described above (see Akt phosphorylation studies). The antibodies used in the present study were obtained from the following sources: anti-phospho-ser ${ }^{473}$-Akt and phospho-thr ${ }^{172}$-AMPK $\alpha$ from Cell Signaling; anti-tubulin, anti-AMPK $\alpha$ 1/2 and anti-GLUT4 from Santa Cruz Biotech.

Cell proliferation assay. Cells were seeded onto 24-well culture dishes (80000 cells /wells) in DMEM supplemented with $10 \%$ FCS. After $24 \mathrm{~h}$, subconfluent cultures were washed twice with DMEM and incubated for $24 \mathrm{~h}$ in fresh medium without FCS in the absence or in the presence of the compounds under test. At the end of incubation, cells were trypsinized and counted in a Burker chamber. In a second series of experiments, cell proliferation was determined measuring ${ }^{3} \mathrm{H}-$ thymidine $(0.5 \mu \mathrm{Ci} /$ well, Amersham Biosciences Europe $\mathrm{GmbH})$ incorporation over the last $16-\mathrm{h}$ of culture. At the end of the incubation, the medium was discarded, cells were washed two times with PBS and incubated for $10 \mathrm{~min}$ in $5 \%$ trichloroacetic acid (TCA) at $4{ }^{\circ} \mathrm{C}$; after two more washes with PBS, cells were lysed with $2 \%$ SDS and incorporated radioactivity was measured in a liquid scintillation counter. 
Analysis of extranuclear DNA fragmentation. Cells were seeded onto 10-cm culture plates and allowed to grow to confluency. Confluent myoblasts were switched to medium without FCS and treated with different doses of olanzapine or clozapine for $48 \mathrm{~h}$, in the presence or in the absence of $10 \mathrm{nM}$ insulin. In a second series of experiments, confluent cells were switched to the differentiating medium, containing $2 \% \mathrm{HS}$, and treated with olanzapine for $48 \mathrm{~h}$. Then, cells were washed twice in PBS, scrapped and pelleted at $4^{\circ} \mathrm{C}$. To isolate extranuclear DNA we used the method of Lyons et al. modified as previously described (Conejo et al. 2001). DNA was dissolved in Tris-EDTA buffer containing 30\% glycerol, $1 \mu \mathrm{g} / \mathrm{ml}$ ethidium bromide, and electrophoresed in a $1.5 \%$ agarose gel. The gel was visualized and photographed under transmitted UV light.

Trypan blue exclusion assay. $\mathrm{C} 2 \mathrm{C} 12$ cell cultures were exposed to various clozapine or olanzapine concentrations, as described previously. At 48 hours after exposure, 0.25\% trypan blue (Biochrom KG, Berlin, Germany) in PBS was applied to cultures for $5 \mathrm{~min}$, and then cultures were rinsed twice with PBS. As a positive control, some untreated cultures were exposed to $80 \%$ ethanol in PBS for 30 min prior to trypan blue application. The cultures were then microscope analyzed under the $20 \times$ objective (yielding a total magnification of $200 \times$ ) for the presence of stained cells.

Analysis of protein synthesis. Based on microscope analysis of cells after staining with Giemsa (Merck, Darmstadt, Germany), on day 5 in medium supplemented with 2\% HS, approximately $70 \%$ of cells were fused. Fresh myotubes were analyzed for protein synthesis using procedures adapted from Desler et al. with the following modifications: cells were serum-starved overnight; then, they were incubated in DMEM supplemented with stimuli for $2 \mathrm{~h}$ and labeled with $1 \mu \mathrm{Ci} / \mathrm{ml}$ of $\left[{ }^{3} \mathrm{H}\right]$ tyrosine for an additional $2 \mathrm{~h}$. After TCA treatment, cells were dissolved in distilled water containing $2 \%$ SDS $\left(30 \mathrm{~min}, 37^{\circ} \mathrm{C}\right)$. Incorporated radioactivity was measured in a liquid scintillation counter (Wallac, Turku, Finland) using UltimaGold (Beckman). The non-specific uptake, as measured in the presence of cycloheximide $(50 \mu \mathrm{g} / \mathrm{ml})$, was lower than $1 \%$ of control values. 
Statistical analysis. Unless othewise stated, results are presented as the means \pm SD of four independent experiments, with four replicate wells for each experiment. The statistical significance of the differences between the mean value for untreated control cells and the mean values with stimuli was assessed by one-way repeated-measures ANOVA followed by Dunnett's $t$ test. The analysis by nonparametric test (Friedman's test followed by Dunn's) gave similar results. A P value $<0.05$ was considered significant. 


\section{RESULTS}

\section{Effects of olanzapine on basal- and insulin-stimulated glucose transport.}

Olanzapine and $\alpha$-methyl-5-HT stimulated 2-deoxyglucose uptake in C2C12 myoblasts in a dosedependent manner but over a narrow range of concentrations (figure 1A). Olanzapine was more potent than $\alpha$-methyl-5-HT (minimal effective dose: $2 \mu \mathrm{M}$ olanzapine and $10 \mu \mathrm{M} \alpha$-methyl-5-HT). Treatment with clozapine had no effect on glucose transport (figure 1A). The study of 2DG uptake as a function of the total exposure time to olanzapine, has showed that the maximal effect occurred in 2 hours and did not decrease even after 72 hours of exposure (figure 1B). The olanzapineinduced increase of glucose transport was most likely mediated by glucose transporters (i.e. GLUT4 and GLUT1), because 2DG uptake in the presence of cytochalasin B was negligible (table 1). The exposure of cells to the inhibitor of protein synthesis, cycloheximide, did not reduce the stimulatory effect of olanzapine on 2DG uptake (table 1). To better understand the basis for the stimulatory effect of olanzapine on glucose transporters activity, we measured the kinetics of 2DG uptake in the presence of olanzapine or insulin versus basal uptake (figure 2A). The kinetics of glucose transport is based on facilitated diffusion and can be analyzed similarly to an enzymatic reaction (BenAbraham et al., 2003; Louters et al., 2006 ). The values for maximum transport velocity (Vmax) and the Michaelis-Menten constant (Km) were computed using nonlinear regression (GraphPad Prism software 3.0), making the assumption that only glucose transporters with similar Km were involved. The best-fit curves and the coefficients of determination are shown in figure $2 \mathrm{~A}$. Both insulin and olanzapine caused an increase of $\mathrm{V}_{\max }$ (table 2). Exposing $\mathrm{C} 2 \mathrm{C} 12$ cells simultaneously to insulin and olanzapine resulted in the additive stimulation in 2DG uptake (figure 2B).

We investigated whether components of the insulin-signaling pathway may participate in mediating the stimulatory effect of olanzapine on glucose transport in $\mathrm{C} 2 \mathrm{C} 12$ cells. The phosphoinositide-3kinase (PI3K) inhibitor, wortmannin, induced a $60 \%$ reduction in basal glucose uptake and completely blocked insulin-stimulated glucose transport. Olanzapine was still capable of causing a significant stimulation of glucose uptake in the presence of wortmannin (table 1). Protein kinase 
Akt (PKB) lies downstream of PI3K and PI3K-dependent Akt phosphorylation has been implicated in the insulin-induced increase of glucose transporter-4 (GLUT4) activity (Saltiel et al., 2002). In $\mathrm{C} 2 \mathrm{C} 12$ cells, insulin provoked a clear-cut increase in Akt phosphorylation but cells exposed to 20 $\mu \mathrm{M}$ olanzapine did not display any detectable increase of phosphorylated Akt levels (figure 3A). Insulin regulates the uptake of glucose into skeletal muscle and adipocytes by redistributing GLUT4 from intracellular vesicles to the cell surface. We studied the subcellular distribution of GLUT4 by immunoblotting of plasma membrane (PM) fractions and whole-cell homogenates from $\mathrm{C} 2 \mathrm{C} 12$ cells, with an antibody against GLUT4. Since GLUT4 contains a putative N-glycosylation site in its first extracellular loop (Saltiel et al., 2002; Tortorella et al., 2002), glycosylated proteins have been partially enriched using Concanavalin-A-sepharose beads. In C2C12 cells, GLUT4 was not detected as a single band but rather as a group of closely migrating bands. Insulin and olanzapine increased the plasma membrane abundance of GLUT4, without changing GLUT4 content in the whole cell (figure 3B). The pre-incubation of $\mathrm{C} 2 \mathrm{C} 12$ cells in buffered salt solution supplemented with Dglucose or sodium pyruvate reduced basal 2DG uptake by $40 \%$ but it did not prevent the increase of glucose transport, following the exposure to insulin or olanzapine (table 1).

Reportedly, the activation of the adenosine 5'-monophosphate-activated protein kinase (AMPK) increases translocation of GLUT4 to plasma membrane in skeletal muscle cells (Steinberg et al., 2007). The activity of AMPK is primarily dependent on phosphorylation of $\mathrm{thr}^{172}$ in the activation loop of its $\alpha$-subunit by the upstream kinase LKB1. AMP activates AMPK allosterically, in that its binding to AMPK facilitate phosphorylation of $\mathrm{thr}^{172}$. We investigated whether AMPK may have a role in mediating olanzapine effects on glucose transport in $\mathrm{C} 2 \mathrm{C} 12$ cells. We used the synthetic compound AICAR as the reference compound. Inside the cells, AICAR is converted to the AMP analog AICAR-5'-monophosphate which, in turn, is able to activate AMPK. As expected, the immunoreactivity for phospho-thr ${ }^{172}$-AMPK was approximately two-fold greater in $\mathrm{C} 2 \mathrm{C} 12$ myotubes incubated in the presence of $1 \mathrm{mM}$ AICAR compared with untreated cells, in agreement 
with data from Smith and coworkers (Smith et al., 2005a). As compared with AICAR, olanzapine did not significantly increase the levels of phosphorylated AMPK (figure 4A).

The treatment with $1 \mathrm{mM}$ AICAR by itself raised the rate of 2DG uptake above baseline by approximately $35 \%$ in $\mathrm{C} 2 \mathrm{C} 12$ cells (figure 4B). When AICAR was added to the incubation medium containing 10- or $40 \mu \mathrm{M}$ olanzapine, it did not increase glucose transport above the separate effect of olanzapine (figure 4B).

Since 5-HT causes a rapid stimulation in glucose uptake in both L6 myotubes and C2C12 myoblasts through 5-HT $2 \mathrm{~A}$ activation (Hajduch et al. 1999; Tulipano et al., 2007), we hypothesized that the stimulatory effect of olanzapine on glucose uptake would depend on a partial agonist activity at murine $5-\mathrm{HT}_{2 \mathrm{~A}}$ receptor. Actually, olanzapine proved to be more effective than the full 5-HT $2 \mathrm{~A}$ receptor agonist, $\alpha$-methyl-5-HT, at inducing the increase of 2DG uptake in C2C12 cells (figure 1A). Clozapine completely suppressed the stimulatory effects of $\alpha$-methyl-5-HT and caused a modest decrease of 2DG uptake in the presence of olanzapine (figure 5). The difference between the effects of olanzapine in the absence or the presence of clozapine did not attain statistical significance (figure 5). Exposing C2C12 cells simultaneously to olanzapine and $\alpha$-methyl-5-HT did not result in any additive stimulation in glucose transport (2DG uptake as a \% of basal uptake: 10 $\mu \mathrm{M}$ olanzapine, $142 \pm 6 ; 10 \mu \mathrm{M} \alpha$-methyl-5-HT, $116 \pm 5 ; 10 \mu \mathrm{M}$ olanzapine $+10 \mu \mathrm{M} \alpha$-methyl-5$\mathrm{HT}, 145 \pm 7$ as mean $\pm \mathrm{SD}$ of four replicates).

We decided to test the effects of olanzapine on 2DG uptake in in human rabdomyosarcoma cells (RD cells). In our hands, these cells exhibited high basal 2DG uptake, most likely mediated by glucose transporters as it was sensitive to cytochalasin B, and were not responsive to insulin, suggesting that the accessibility of their glucose transporters on cell surface can not be regulated by external signals. Olanzapine failed to elicit any increase of 2DG uptake in RD cells (2DG uptake as a \% of basal uptake: $100 \mathrm{nM}$ insulin, $89 \pm 7 ; 20 \mu \mathrm{M}$ olanzapine, $95 \pm 5 ; 40 \mu \mathrm{M}$ olanzapine, $100 \pm 7$ as mean $\pm \mathrm{SD}$ of four replicates). This finding rules out the possibility that the increase in glucose 
uptake elicited by olanzapine in $\mathrm{C} 2 \mathrm{C} 12$ cells, may be mediated by non selective changes of lipid bilayer permeability.

\section{Effects of olanzapine on $\mathrm{C} 2 \mathrm{C} 12$ cell proliferation and survival, and growth of differentiated myotubes}

Reportedly, insulin is mitogen for $\mathrm{C} 2 \mathrm{C} 12$ myoblasts and produces a maximal effect of approximately fourfold increase of ${ }^{3} \mathrm{H}$-Thymidine incorporation relative to control cells at $10 \mathrm{nM}$ (Conejo et al., 2001). Moreover, insulin is able to rescue serum-deprived myoblasts from apoptosis (Conejo et al., 2001). Apoptosis is often accompanied by a rapid cleavage of the cellular DNA into multiples of $180 \mathrm{bp}$, corresponding to internucleosomal spacing, and the "180-bp ladder" can be seen upon electrophoresis of DNA from apoptotic cells. Insulin prevents DNA laddering occurring under serum deprivation in $\mathrm{C} 2 \mathrm{C} 12$ cells (Conejo et al., 2001). In the present study, we investigated the effects of olanzapine, as compared with clozapine, on insulin-induced cell proliferation and rescue from apoptosis. We checked $\mathrm{C} 2 \mathrm{C} 12$ cell viability by Trypan blue exclusion assay. The exposure to various concentrations of clozapine or olanzapine did not affect the cell membrane permeability to trypan blue of proliferating cells and differentiated myotubes. Based on cell counting, when subconfluent cultures of $\mathrm{C} 2 \mathrm{C} 12$ cells were incubated with clozapine, a significant inhibition of both basal- and insulin-induced cell proliferation was observed (minimal effective dose, $20 \mu \mathrm{M}$ ) (figure 6A). On this line, clozapine reduced ${ }^{3} \mathrm{H}$-Thymidine incorporation to approximately $50 \%$ of vehicle-treated cells (figure 6B). The treatment with olanzapine did not cause any change in cell proliferation (figure 6A). As expected, insulin reduced DNA laddering occurring under FCS deprivation in proliferating myoblasts (figure 6C). Neither olanzapine nor clozapine changed significantly the pattern of DNA laddering in the absence or the presence of insulin (figure $6 \mathrm{C})$.

We have previously shown that the addition of $20 \mu \mathrm{M}$ clozapine to growth medium supplemented with HS, for 48 hours post-differentiation, does not significantly change the final width of $\mathrm{C} 2 \mathrm{C} 12$ myotubes as documented by staining with Giemsa and microscope analysis (Tulipano et al., 2007). 
In the present study, we obtained similar results as far as olanzapine is concerned (data not shown). We preferred to show that olanzapine did not induce DNA laddering in differentiating myoblasts (figure 6D) and did not affect both basal- and insulin induced-protein synthesis in differentiated myotubes $\left({ }^{3} \mathrm{H}\right.$-tyrosine incorporation as a $\%$ of basal incorporation: $2 \mu \mathrm{M}$ olanzapine, $106 \pm 4 ; 20$ $\mu \mathrm{M}$ olanzapine, $103 \pm 5$; $100 \mathrm{nM}$ insulin, $120 \pm 5$; insulin and $2 \mu \mathrm{M}$ olan., $120 \pm 6$; insulin and $20 \mu \mathrm{M}$ olan. $116 \pm 5$ as mean $\pm \mathrm{SD}$ of four replicates). 


\section{DISCUSSION}

The most intriguing information provided by this study is that olanzapine appears to have a direct action in murine skeletal muscle cells, inducing glucose transport through an unknown mechanism. Olanzapine is classified as a thienobenzodiazepine and is structurally related to clozapine, a dibenzodiazepine. Both drugs belong to atypical antipsychotic drugs and are antagonists at multiple neurotransmitter receptors, showing a similar receptor binding profile (Casey et al., 2001; Melkersson et al., 2004). We have previously shown that clozapine does not affect glucose transport in murine myoblasts (Tulipano et al., 2007). Like insulin, olanzapine increases the Vmax of glucose transport, suggesting an increase in the concentration of available transporters on cell surface. This effect is not dependent on protein synthesis and is sustained with prolonged exposure of cells to olanzapine. The mechanism whereby olanzapine is capable of increasing glucose uptake appears to be distinct from insulin, based on the use of inhibitors of insulin signaling pathways and the study of the phosphorylation status of Akt. The 2-hour long exposure to olanzapine did not modulate the levels of phosphorylated Akt in the absence or in the presence of insulin, suggesting that Akt does not partecipate in olanzapine signaling in $\mathrm{C} 2 \mathrm{C} 12$ cells. Engl and co-workers have reported that olanzapine diminished the insulin-stimulated Akt phosphorylation in L6 myoblasts. Actually, they used quite different experimental conditions in that they exposed cells to higher concentrations of olanzapine $(100 \mu \mathrm{M})$ and for 72 hours (Engl et al., 2005).

In skeletal muscle, an exercise (or hypoxia)-induced rise in AMP results in activation of the AMPactivated protein kinase (AMPK), which correlates with increased glucose transport. The exercisedependent activation of GLUT4 is not PI3K dependent (Steinberg et al., 2007). In the current study, given the 2-hour incubation of myoblasts in buffered salt solution before the glucose uptake assay, an increase of cellular AMP levels and the subsequent activation of AMPK are expected. Indeed, the addition of metabolic ATP sources, like D-glucose or sodium pyruvate, to the pre-incubation medium decreased basal 2DG uptake by $40 \%$ in $\mathrm{C} 2 \mathrm{C} 12$ cells. The olanzapine-induced increase in 
2DG uptake did not differ significantly between the two experimental conditions, suggesting that high levels of activated AMPK are not necessary for olanzapine effect on glucose transport.

We investigated whether olanzapine treatment may by itself activate AMPK. Reportedly, C2C12 cells are an appropriate model for this kind of studies (Steinberg et al., 2007; Smith et al. 2005a). The western blot analysis of phospho-thr ${ }^{172}$-AMPK levels did not evidence any effect of olanzapine on AMPK activation, compared with AICAR. Actually, the lack of any further increase in glucose transport in $\mathrm{C} 2 \mathrm{C} 12$ cells exposed simultaneously to AICAR and olanzapine above the separate effect of olanzapine, suggest a point of convergence between AICAR- and olanzapine signaling pathways.

Insulin-stimulated glucose uptake is primarily mediated by the facilitative transporter GLUT4 in skeletal muscle and adipose tissue. Insulin stimulates the translocation of an intracellular pool of GLUT4 to the plasma membrane through a process of targeted exocytosis. At the same time, the rate of GLUT4 endocytosis is somewhat attenuated (Saltiel et al., 2002). Skeletal muscle cell lines, like L6 and C2C12 cells, express far less GLUT4 than skeletal muscle tissue and adipocytes (Tortorella et al., 2002). Consequently, the insulin responsiveness is reduced, although clearly detectable (Hajduch et al. 1999; Tulipano et al., 2007), in C2C12 cells as compared with skeletal muscle speciments or 3T3L1 adipocytes. We studied the subcellular distribution of GLUT4 in $\mathrm{C} 2 \mathrm{C} 12$ cells, in the presence or the absence of effective concentrations of olanzapine and insulin. GLUT4 is a glycoprotein and contains one possible N-glycosylation site in its first extracellular loop (Saltiel et al., 2002; Tortorella et al., 2002). In order to facilitate the analysis of GLUT4 expression by western blot, we decided to perform a partial purification of glycosylated proteins using Concanavalin-A-sepharose beads. As expected, GLUT4 was not detected as a single band by SDS-PAGE but rather as a group of closely-migrating bands. This pattern is likely due to extensive variation in the carbohydrate processing at the $\mathrm{N}$-glycosylation site occurring in $\mathrm{C} 2 \mathrm{C} 12$ cells. It has been previously suggested that $\mathrm{C} 2 \mathrm{C} 12$ cells lack an insulin-sensitive intracellular storage compartment of GLUT4 (Tortorella et al., 2002). In our hands, insulin and olanzapine significantly 
increased plasma membrane associated GLUT4 in C2C12 cells, without altering GLUT4 expression. Our western blot analysis showed that a single GLUT4 band, which most likely represents a specific glycosylated form of GLUT4, is translocated to plasma membrane in response to external stimuli. This result leads to the following hypothesis: in C2C12 cells, a GLUT4 pool traffics in an insulin-sensitive fashion but it is possible that extensive carbohydrate processing generates aberrant glycosylated forms of GLUT4 that are defective regarding their targeting and function.

We have not so far determined the receptor mediating the stimulatory effect of olanzapine on glucose uptake in $\mathrm{C} 2 \mathrm{C} 12$ cells. It has been shown that 5-HT causes a rapid stimulation in glucose uptake in both L6 myotubes and C2C12 myoblasts (Hajduch et al. 1999; Tulipano et al., 2007). This activation is mediated via the 5-HT receptor subtype-2A. Although atypical antipsychotics act as antagonists at $5-\mathrm{HT}_{2}$ receptors in humans, olanzapine-induced increase of glucose uptake may suggest intrinsic agonist activity at the mouse variant of $5 \mathrm{HT}_{2 \mathrm{~A}}$. The finding that clozapine suppressed the stimulatory effect of the $5-\mathrm{HT}_{2 \mathrm{~A}}$ agonist $\alpha$-methyl-5-HT and failed to reduce significantly the increase in glucose uptake elicited by olanzapine in $\mathrm{C} 2 \mathrm{C} 12$ cell cultures, argues against this hypothesis.

Recently, it has been suggested the possibility of novel autocrine signaling in C2C12 myotubes in which levodopa, produced by myotubes, could have hormone-like effects that prevent the stimulation of glucose transport by insulin. The specific receptor that mediates these effects of levodopa has not been identified yet (Smith et al., 2005b). Acting as an antagonist at multiple neurotransmitter receptors, olanzapine might interfere with the levodopa-mediated autocrine signaling in cultured cells. Actually, we showed that olanzapine activates glucose uptake in the basal state whereas, reportedly, depletion of endogenous levodopa has no effect on glucose transport in the absence of insulin (Beaulieu et al. 2007; Smith et al., 2005b).

The last part of the study focused on potential adverse effects of atypical antipsychotics on proliferating myoblasts and differentiated myotubes. Neither clozapine nor olanzapine affected 
C2C12 cell viability, as assessed by Trypan blue exclusion assay. Clozapine, but not so olanzapine, had a negative impact on $\mathrm{C} 2 \mathrm{C} 12$ cell proliferation. Clozapine-induced inhibition of myoblast proliferation, may suggest an adverse effect on skeletal muscle fiber regeneration, upon muscle disease or direct injury in patients. Actually, this inhibitory effect may also resemble in vitro aspecific, slight toxicity. Proliferating C2C12 myoblasts undergo growth arrest and apoptosis under 48-h long serum deprivation, as detected by DNA laddering. Reportedly, downstream of PI3-kinase, activation of Akt contributes to insulin rescue from apoptosis. Neither Olanzapine nor clozapine affected significantly insulin rescue from apoptosis in cultured $\mathrm{C} 2 \mathrm{C} 12$ cells. Altogether, this findings further support the conclusion that olanzapine does not suppress insulin activity and, in detail, insulin-dependent Akt phosphorylation and activation in myoblasts. Morphological analysis at microscope, DNA laddering study and protein synthesis determination did not evidence any adverse effect of olanzapine on differentiating cells and differentiated myotubes.

The major restriction in translating results obtained in the cell culture system to clinical practice of patients on antipsychotic treatment, is the difference between the therapeutic plasma levels of olanzapine and clozapine (maximal plasma concentrations 0.3 and $3 \mu \mathrm{M}$, respectively) (Catafau AM et al., 2008) and the concentrations that have been used in the present study and in previously published in vitro studies, ranging from 1 to $100 \mu \mathrm{M}$. Actually, it has been documented that antipsychotic drugs accumulate in the brain, in fat tissue and in the liver to levels that are 25-30 times higher than the therapeutic plasma levels (Aravagiri et al., 1999). Thus, therapeutic plasma concentrations of clozapine and olanzapine may be considerably lower than their respective concentrations in skeletal muscles, as well.

In conclusion, the finding that olanzapine can positively modulate glucose transport in murine myoblast-like cells and myotubes, is consistent with the acute lowering of plasma glucose/insulin concentrations that occurs in rats before olanzapine-induced overeating (Albaugh et al., 2006). Remarkably, the structurally related compound clozapine, which has no effects on food intake and body weight in rats, is not able to increase glucose uptake in skeletal muscle cell cultures. Based on 
the above mentioned paper by Engl and coworkers, we may add that olanzapine is also likely to uncouple glucose uptake and glycogen synthesis in skeletal muscle cells, with possible detrimental effects on cellular energy pathways.

\section{Acknowledgements}

The authors are grateful to Eli Lilly (Indianapolis, USA) for the gift of their compound olanzapine and to Michela Giovannini for her technical assistance.

The authors declare that they do not have any financial involvement with Eli Lilly and have not received any financial support from Eli Lilly for their study.

This study was supported by a grant from University of Brescia (Italy). 


\section{REFERENCES}

Aravagiri M, Teper Y, Marder SR., 1999. Pharmacokinetics and tissue distribution of olanzapine in rats. Biopharm. Drug Dispos. 20: 369-377.

Albaugh VL, Henry CR, Bello NT, Hajnal A, Lynch SL, Halle B, Lynch CJ., 2006. Hormonal and metabolic effects of olanzapine and clozapine related to body weight in rodents. Obesity 14: $36-50$.

Arjona AA, Zhang SX, Adamson B, Wurtman RJ., 2004. An animal model of antipsychoticinduced weight gain. Behav. Brain Res. 152: 121-127.

Baptista T, Mata A, Teneud L, de Quijada M, Han HW, Hernandez L., 1993. Effects of longterm administration of clozapine on body weight and food intake in rats. Pharmacol. Biochem. Behav. 45: 51-54.

Beaulieu JM, Gainetdinov RR and Caron MG., 2007. The Akt-GSK-3 signaling cascade in the actions of dopamine. TRENDS in Pharmacological Sciences 28: 166-172.

Ben-Abraham R, Gazit V, Vofsi O, Ben-Shlomo I, Reznick AZ, Katz Y., 2003. Betaphenylpyruvate and glucose uptake in isolated mouse soleus muscle and cultured C2C12 muscle cells. Journal of Cellular Biochemistry 90: 957-963.

Casey DE, Zorn SH., 2001. The pharmacology of weight gain with antipsychotics. J. Clin. Psychiatry 62 (suppl. 7): 4-10.

Catafau AM, Penego MM, Nucci G, Bullich S, Corripio I, Parellada E, Garcia-Ribera C, Gomeni R, Merlo-Pich E., 2008. Pharmacokinetics and time-course of D2 receptor occupancy induced by atypical antipsychotics in stabilized schizophrenic patients. J. Psychopharmacol. Epub ahead of print.

Conejo R and Lorenzo M., 2001. Insulin signaling leading to proliferation, survival, and membrane ruffling in C2C12 myoblasts. Journal of Cellular Physiology 187: 96-108. 
Desler MM, Jones SJ, Smith CW and Woods TL., 1996. Effects of dexamethasone and anabolic agents on proliferation and protein synthesis and degradation in $\mathrm{C} 2 \mathrm{C} 12$ myogenic cells. Journal of Animal Sciences. 74: 1265-1273.

Engl J, Laimer M, Niederwanger A, Kranebitter M, Starzinger M, Pedrini MT, Fleischhacker WW, Patsch JR and Ebenbichler CF., 2005. Olanzapine impairs glycogen synthesis and insulin signaling in L6 skeletal muscle cells. Molecular Psychiatry 10: 1089-1096.

Fadel J, Bubser M, Deutch AY., 2002. Differential activation of orexin neurons by antipsychotic drugs associated with weight gain. J. Neurosci. 22: 6742-6746.

Hajduch E, Rencurel F, Balendran A, Batty IH, Downes P and Hundal HS., 2999. Serotonin (5hydroxytryptamine), a novel regulator of glucose transport in rat skeletal muscle. Journal of Biological Chemistry 274: 13563-13568.

Henderson DC., 2002. Atypical antipsychotic-induced diabetes mellitus: how strong is the evidence? CNS Drugs 16: 77-89.

Holt RIG, Peveler RC, Byrne CD., 2004. Schizophrenia, the metabolic syndrome and diabetes. Diabet. Med. 21: 515-523.

Houseknecht KL, Robertson AS, Zavadoski W, Gibbs EM, Johnson DE and Rollema H., 2007. Acute effects of atypical antipsychotics on whole-body insulin resistance in rats: implications for adverse metabolic effects. Neuropsychopharmacology 32: 289-297.

Kapur S, VanderSpek SC, Brownlee BA, Nobrega JN., 2003. Antipsychotic dosing in preclinical models is often unrepresentative of the clinical condition: a suggested solution based on in vivo occupancy. J. Pharmacol. Exp. Ther. 305: 625-631.

Kaur G, Kulkarni SK., 2002. Studies on modulation of feeding behavior by atypical antipsychotics in female mice. Prog. Neuro-Psychopharmacol. Biol. Psychiatry 26: 277-285.

Lamey, M., Thompson, M., Varghese, G., Chi, H., Sawzdargo, M., George, S. R., and O'Dowd, B. F., 2002. Distinct residues in the carboxyl tail mediate agonist-induced desensitization and internalization of the human dopamine D1 receptor. J. Biol. Chem. 277: 9415-9421. 
Lee MD, Clifton PG., 2002. Meal patterns of free feeding rats treated with clozapine, olanzapine, or haloperidol. Pharmacol. Biochem. Behav. 71: 147-154.

Louters LL, Dyste SG, Frieswyk D, TeHarmsel A, Vander Kooy TO, Walters L and Whalen T., 2006. Methylene blue stimulates 2-deoxyglucose uptake in L929 fibroblast cells. 78: 586-591. Melkersson K, Dahl ML., 2004. Adverse metabolic effects associated with atypical antipsychotics. Drugs 64: 701-723.

Minet-Ringuet J, Even PC, Valet P, Carpéné C, Visentin V, Prévot D, Daviaud D, QuignardBoulange A, Tomé D and de Beaurepaire R., 2007. Alterations of lipid metabolism and gene expression in rat adipocytes during chronic olanzapine treatment. 12: 562-571.

Mir S, Taylor D., 2001. Atypical antipsychotics and hyperglycemia. International Clinical Psychopharmacology 16: 63-73.

Pouzet B, Mow T, Kreilgaard M, Velschow S., 2003 Chronic treatment with antipsychotics in rats as a model for antipsychotic-induced weight gain in human. Pharmacol. Biochem. Behav. 75: $133-140$.

Ryan MCM, Collins P, Thakore JH., 2003. Impaired fasting glucose tolerance in first-episode, drug-naïve patients with schizophrenia. Am. J. Psychiatry 160: 284-288.

Robinson KA, Wasef SZY and Buse MG., 2006. At therapeutic concentrations, olanzapine does not affect basal or insulin-stimulated glucose transport in 3T3-L1 adipocytes. Progress in Neuro-Psychopharmacology and Biological Psychiatry 30: 93-98.

Saltiel AR and Pessin JE., 2002. Insulin signaling pathways in time and space. TRENDS in Cell Biology 12: 65-71.

Smith JL, Patil PB and Fisher JS., 2005a. AICAR and hyperosmotic stress increase insulinstimulated glucose transport. J. Appl. Physiol. 99: 877-883.

Smith JL, Patil PB, Minteer SD, Lipsitz JR and Fisher JS., 2005b. Possibility of autocrine betaadrenergic signaling in C2C12 myotubes. Experimental Biology and Medicine 230: 845-852. 
Sowell M, Mukhopadhyay N, Cavazzoni P, Carlson C, Mudaliar S, Chinnapongse S, Ray A, Davis T, Breier A, Henry RR, Dananberg J., 2003 Evaluation of insulin sensitivity in healthy volunteers treated with olanzapine, risperidone or placebo: a prospective, randomized study using the two-step hyperinsulinemic, euglycemic clamp. J. Clin. Endocrinol. Metab. 88: 58755880.

Steinberg GR and Jorgensen SB., 2007. The AMP-activated protein kinase: role in the regulation of skeletal muscle metabolism and insulin sensitivity. Mini-reviews in Medical Chemistry 7: 521-528.

Tortorella LL and Pilch PF., 2002. C2C12 myocytes lack an insulin-responsive vesicular compartment despite dexamethasone-induced GLUT4 expression. American Journal of Physiology, Endocrinology and Metabolism 283: 514-524.

Tulipano G, Rizzetti C, Bianchi I, Fanzani A, Spano PF and Cocchi D., 2007 Clozapine-induced alteration of glucose homeostasis in the rat: the contribution of hypothalamic-pituitary-adrenal axis activation. Neuroendocrinology 85: $61-70$.

Vestri HS, Maianu L, Moellering DR and Garvey WT., 2007. Atypical antipsychotic drug directly impair insulin action in adipocytes: effect on glucose transport, lipogenesis, and antilipolysis. Neuropsychopharmacology 32: 765-772. 


\section{LEGEND TO FIGURES}

Figure 1. Panel A. Dose-related effects of olanzapine, clozapine and $\alpha$-methyl-5-HT (2-hours preincubation in DMBS) on basal glucose transport in $\mathrm{C} 2 \mathrm{C} 12$ cells. ${ }^{3} \mathrm{H}$-2-deoxyglucose (2DG) accumulation was measured over 5 min in the absence (basal uptake) or presence of different drug concentrations. Panel B. The 2DG uptake as a function of total exposure time (hours) to olanzapine. C2C12 cells were incubated in DMEM plus vehicle (basal uptake) or $20 \mu \mathrm{M}$ olanzapine for total exposure times of 22 and 70 hours. The medium was switched to buffered salt solution (DMBS) supplemented with the same substances, 2 hours before the 2DG addition. For shorter exposure times, olanzapine was added to the pre-incubation buffered saline $(*, \mathrm{P}<0.05 ; * *, \mathrm{P}<0.01$ vs basal uptake).

Figure 2. Panel A. Kinetics of insulin- and olanzapine-stimulated 2DG uptake versus basal uptake. C2C12 cells were incubated with DPBS in the presence of $20 \mu \mathrm{M}$ olanzapine or its vehicle for 2 hours. Insulin $(100 \mathrm{nM})$ was added to the pre-incubation medium at $30 \mathrm{~min}$ before the uptake assay. The rate of 2DG uptake was measured at varying concentrations of 2DG. The best-fit curves and the coefficients of determination are shown (nonlinear regression analysis). Panel B. Dose-related effect of olanzapine on insulin-stimulated glucose uptake. Cells were pre-incubated with different doses of olanzapine for 2 hours and then exposed to $100 \mathrm{nM}$ insulin for $20 \mathrm{~min}$ before the uptake assay (*, $\mathrm{P}<0.05$ vs insulin-treated cells).

Figure 3. Panel $A$. Immunoblot of native phospho-Akt expression in $\mathrm{C} 2 \mathrm{C} 12$ lysates prepared from control and insulin (Ins)- or olanzapine (Olan)-stimulated cells. Cells were pre-treated with $20 \mu \mathrm{M}$ olanzapine for 2 hours or $100 \mathrm{nM}$ insulin for $30 \mathrm{~min}$ before lysis in RIPA buffer. Lysates were blotted with an antibody that recognizes the phosphorylated $\mathrm{Ser}^{473}$ residue of Akt. The same lysates were blotted with an anti-tubulin antibody. Panel B. Effect of olanzapine and insulin on the abundance of GLUT4 in plasma membrane (PM) protein fractions from $\mathrm{C} 2 \mathrm{C} 12$ cells. Cells were 
incubated with $20 \mu \mathrm{M}$ olanzapine for $2 \mathrm{~h}$, or $100 \mathrm{nM}$ insulin for $30 \mathrm{~min}$, in DPBS prior to cell homogenization and subcellular fractionation as described under "Experimental procedures". A sample of cell homogenates was blotted with GLUT4 antibody after enrichment of glycosylated proteins using ConA-sepharose, in order to detect the whole-cell expression level of GLUT4. Results are representative of three independent experiments. ***, $\mathrm{P}<0.001 ; * *, \mathrm{P}<0.01 ; *, \mathrm{P}<0.05$ vs vehicle treated cells.

Figure 4. Panel $A$. Immunoblot of native phospho-AMPK $\alpha$ expression in $\mathrm{C} 2 \mathrm{C} 12$ lysates prepared from control and AICAR- or olanzapine (Olan)-stimulated cells. See Methods for details. Results are representative of three independent experiments. ${ }^{* *}, \mathrm{P}<0.01$ vs vehicle treated cells. Panel B. Effects of simultaneous exposure to olanzapine and AICAR on glucose uptake in $\mathrm{C} 2 \mathrm{C} 12$ cells. Myotubes were incubated for 1 hour and $30 \mathrm{~min}$ in DMBS containing either olanzapine or its vehicle. Then cells were treated with $1 \mathrm{mM}$ AICAR for $30 \mathrm{~min}$ in the absence or presence of olanzapine, before 2-DG uptake assay (**, $\mathrm{P}<0.01{ }^{*}, \mathrm{P}<0.05$ vs vehicle in the absence of AICAR).

Figure 5. Dose-related effects of clozapine on olanzapine- and $\alpha$-methyl-5-HT-stimulated 2DG uptake in $\mathrm{C} 2 \mathrm{C} 12$ cells. All drugs were added to the pre-incubation medium (DPBS), 2 hours before the uptake assay (*, $\mathrm{P}<0.05 ; * *, \mathrm{P}<0.01$ vs vehicle-treated cells).

Figure 6. Effects of atypical antipsychotics on proliferation and survival in $\mathrm{C} 2 \mathrm{C} 12$ myoblasts. Panel A. Dose-related effects of olanzapine and clozapine on basal- and insulin-stimulated C2C12 cell proliferation. At the end of incubation, cells were trypsinized and counted in a Burker chamber. Panel B. The inhibitory effect of clozapine on $\mathrm{C} 2 \mathrm{C} 12$ cell proliferation was confirmed by ${ }^{3} \mathrm{H}-$ thymidine incorporation assay $(*, \mathrm{P}<0.05 ; * *, \mathrm{P}<0.01$ vs vehicle-treated cells). Error bars are smaller than the symbols representing the mean. Panel $C$. Effects of olanzapine and clozapine on DNA laddering induced by serum deprivation in proliferating myoblasts, in the presence or the 
absence of insulin. Panel D. Effects of olanzapine on DNA laddering in differentiating cells. Cells were scraped and subjected to extranuclear DNA extraction. Purified DNA was electrophoresed in a $1.5 \%$ agarose gel and visualized by UV fluorescence after staining with ethidium bromide. Panels C and $\mathrm{D}$ are representative of three independent experiments. Ins, insulin; Ol, olanzapine; CL, clozapine; FCS, fetal calf serum; HS, horse serum. 


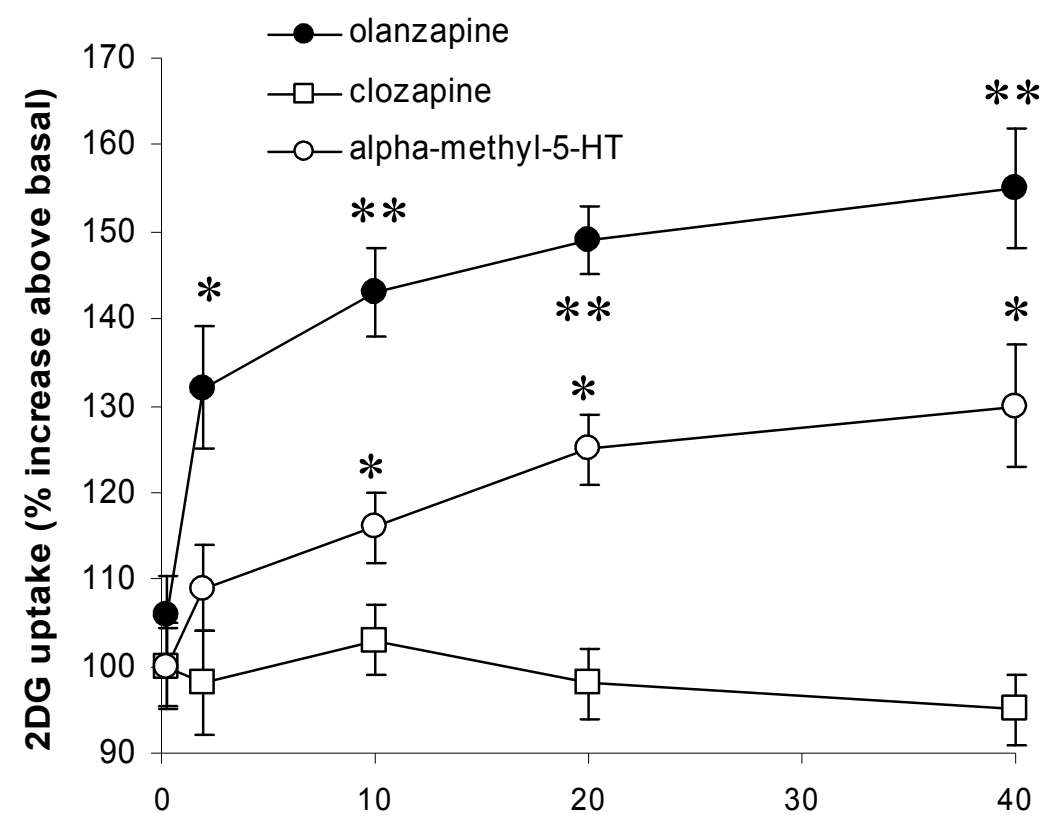

A Concentration ( $\mu \mathrm{M})$

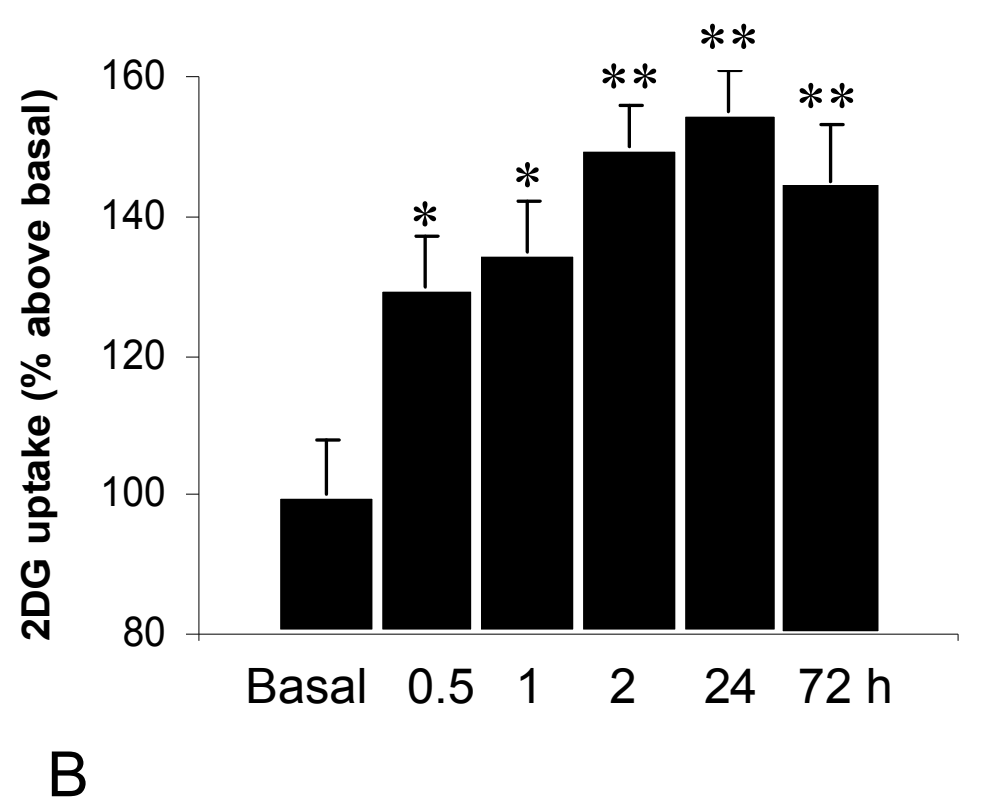

Figure 1 

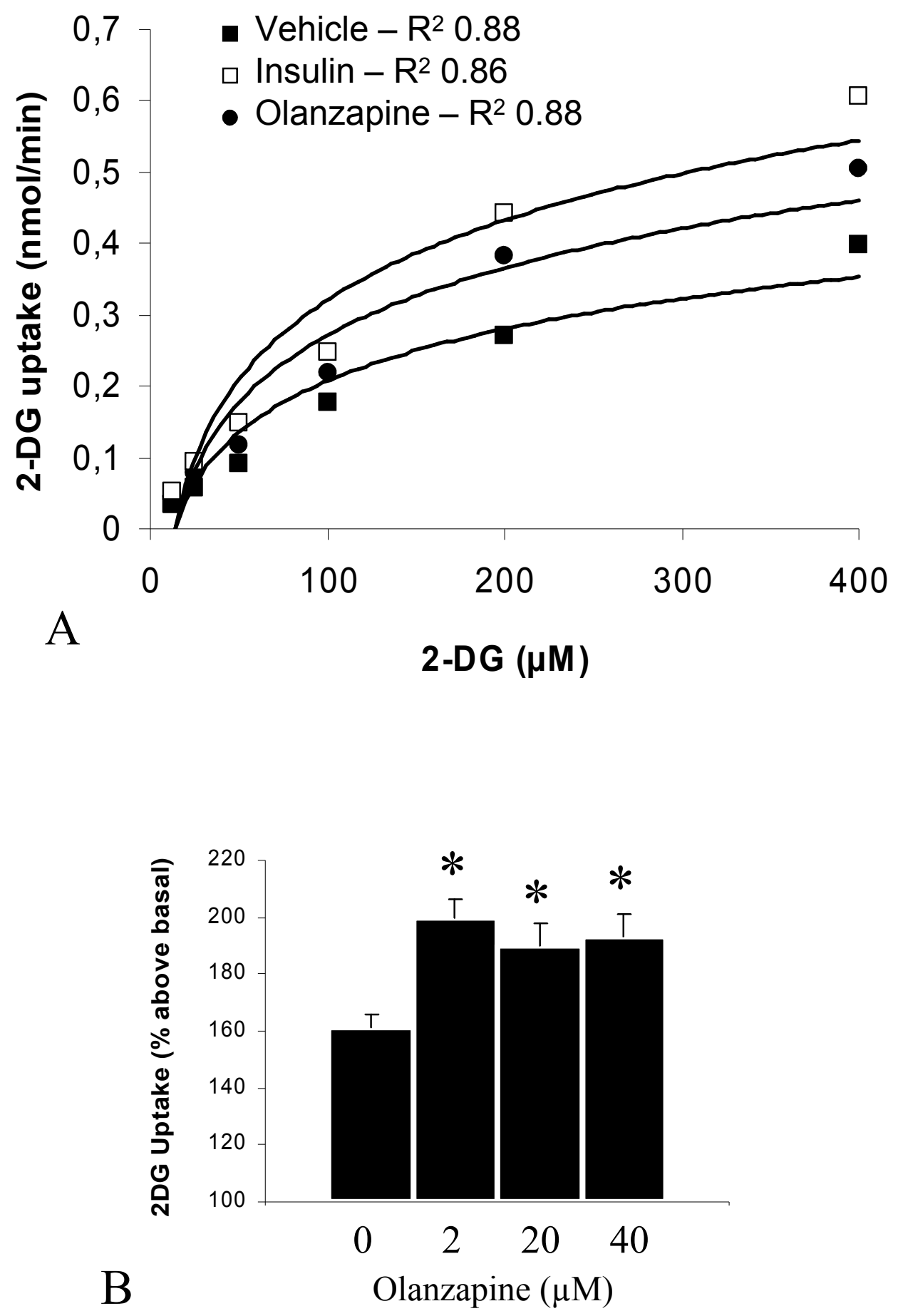

Figure 2 


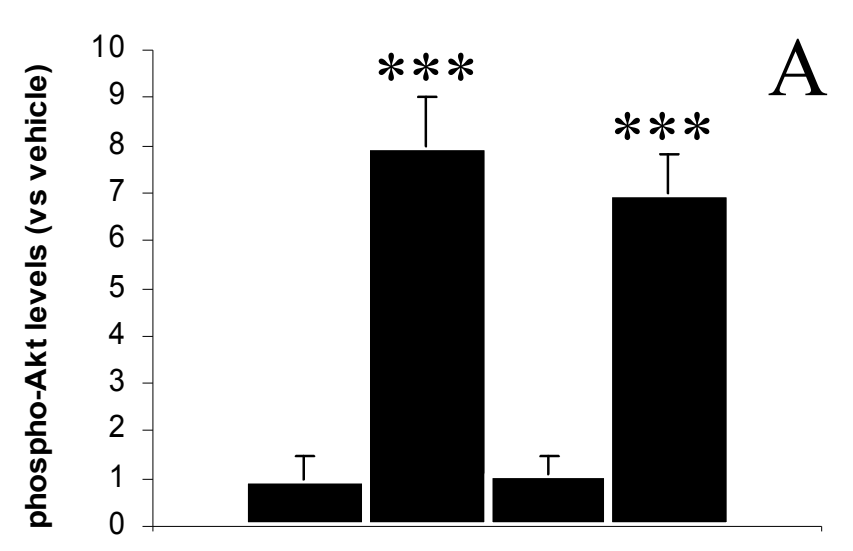

IB: AntiphosphoAkt

IB: Antitubulin

Treatment: Vehicle Ins Olan Ins + Olan

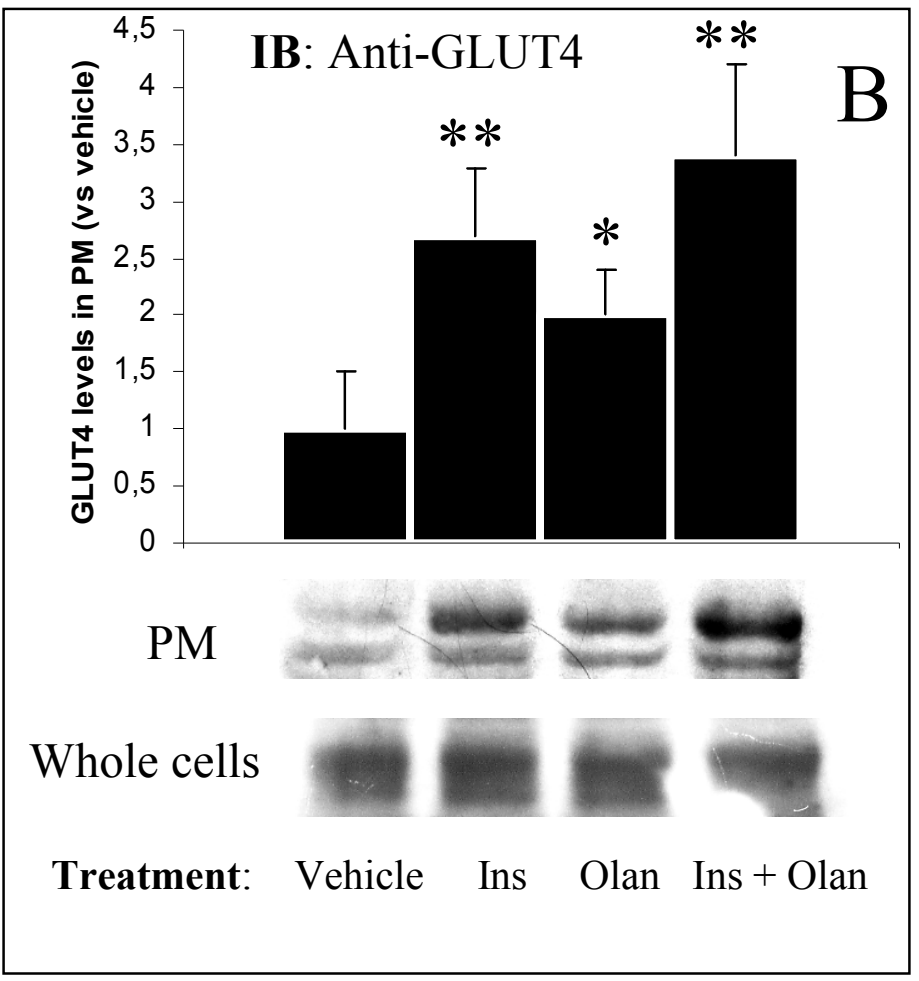

Figure 3 

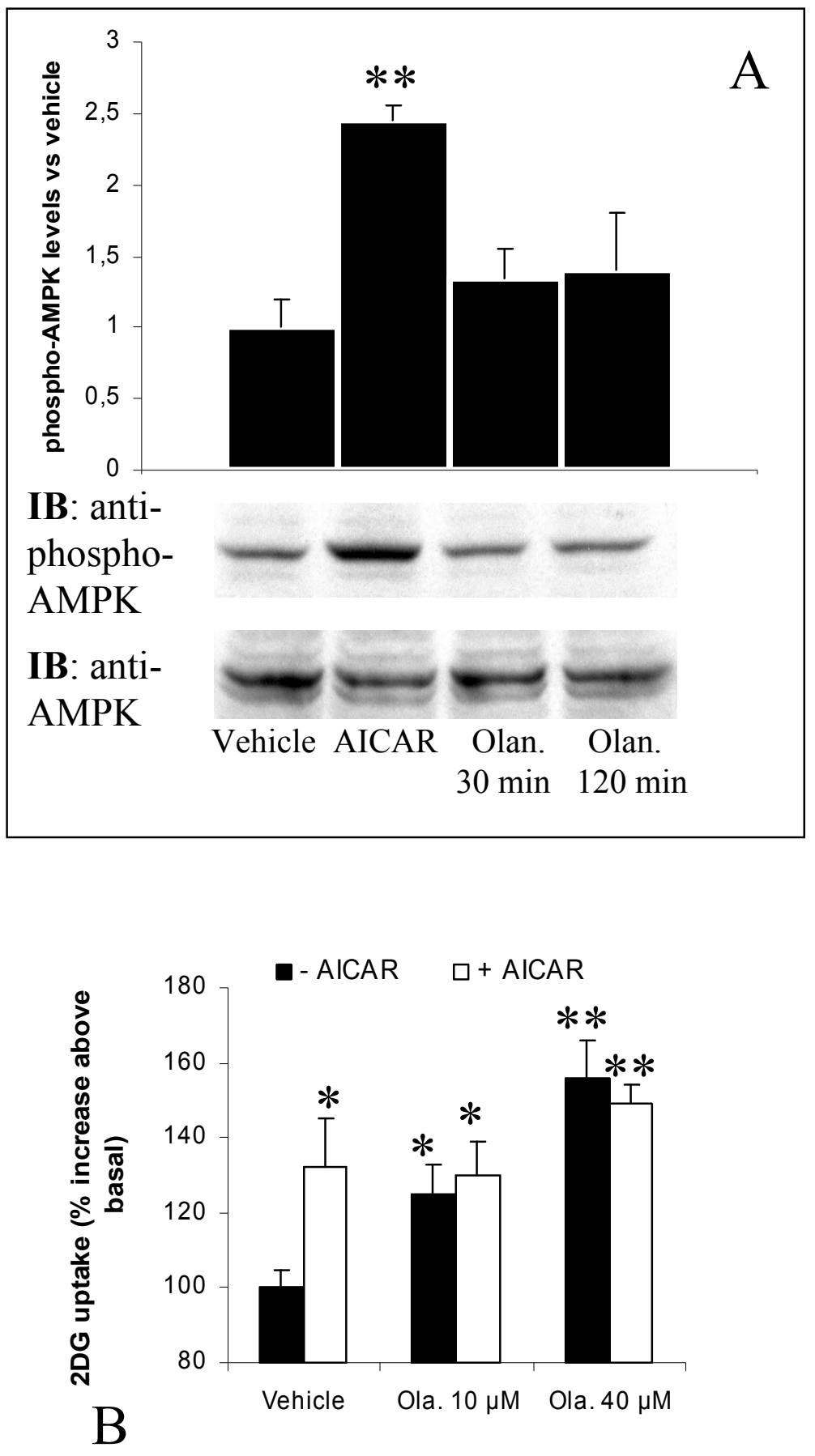

Figure 4 


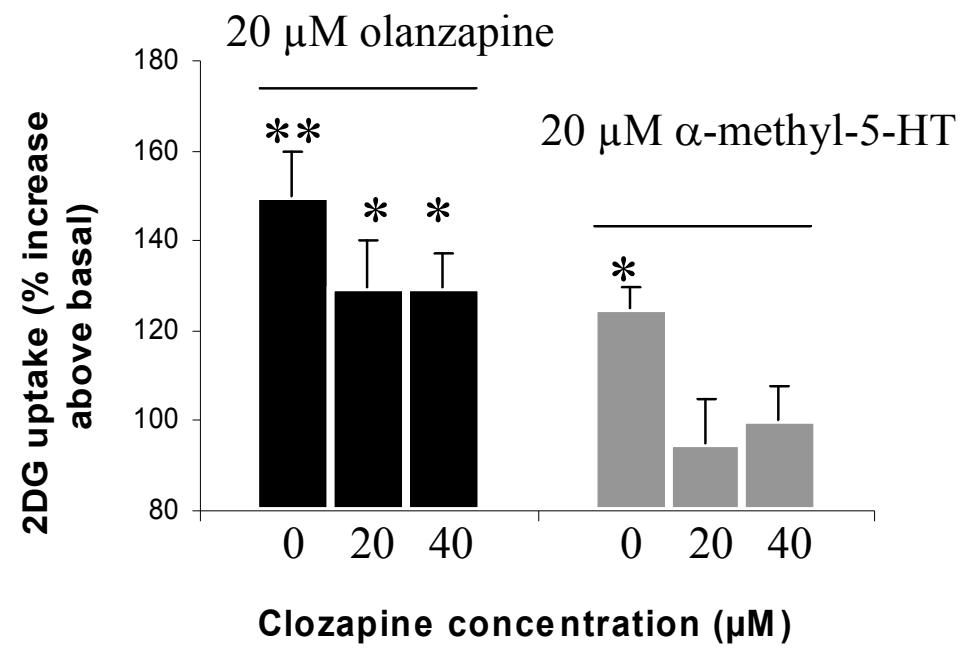

Figure 5 

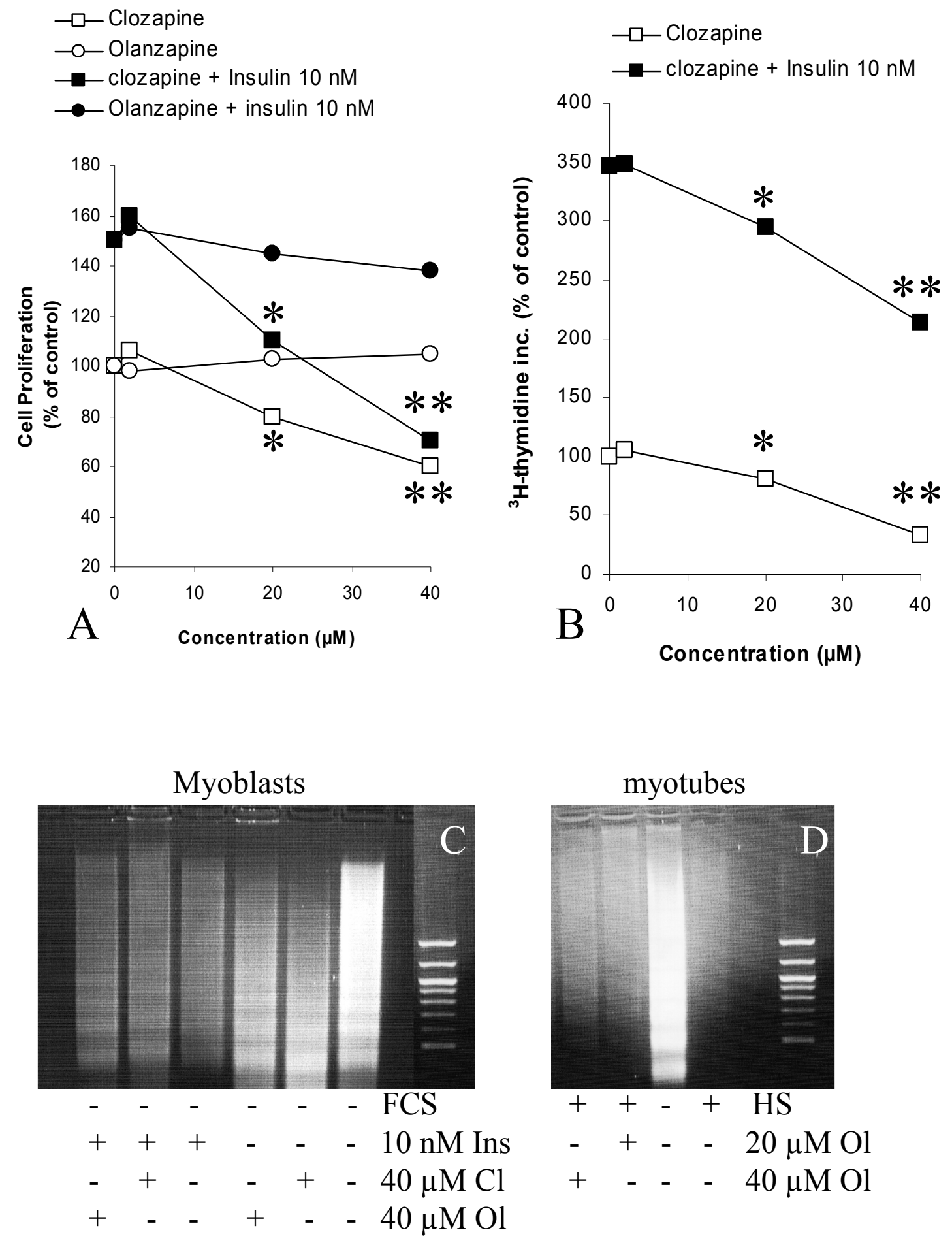

Figure 6 


\begin{tabular}{|c|c|c|c|c|c|}
\hline & $\begin{array}{c}\text { Cytochalasin } \\
\text { B }(1 \mu \mathrm{M})\end{array}$ & $\begin{array}{c}\text { Wortmannin } \\
(100 \mathrm{nM})\end{array}$ & $\begin{array}{c}\text { Cycloheximide } \\
(50 \mu \mathrm{g} / \mathrm{ml})\end{array}$ & $\begin{array}{l}\text { D-glucose } \\
(2.5 \mathrm{mM})\end{array}$ & $\begin{array}{c}\mathrm{Na}^{+} \text {pyruvate } \\
\text { (1 mM) }\end{array}$ \\
\hline $\mathrm{Ve}$ & $20 \pm 4$ & $40 \pm 4$ & $80 \pm 3$ & $60 \pm 5$ & $63 \pm 3$ \\
\hline & 5 & $46 \pm 5$ & $135 \pm 7 * *$ & $120 \pm 7 * *$ & $125 \pm 6^{* *}$ \\
\hline Olanzapine & $25 \pm 3$ & $70 \pm 3 * *$ & $112 \pm 4 * *$ & $85 \pm 6^{*}$ & $90 \pm 7^{*}$ \\
\hline
\end{tabular}

Table 1. Effects of inhibitors and metabolites on basal 2DG uptake and insulin- or olanzapinestimulated 2DG uptake. C2C12 cells were incubated with $20 \mu M$ olanzapine for 2 hours in the absence or the presence of wortmannin, cycloheximide, D-glucose or sodium pyruvate. Cells were stimulated with insulin for 30 min in the absence or the presence of the above-mentioned drugs. . When appropriate, cytochalasin $B$ was added to preincubation media 30 min before the uptake assay. Medium supplemented with $2.5 \mathrm{mM}$ D-glucose was replaced with glucose-free medium, immediately before the uptake assay. Results are expressed as a \% the control values obtained in in the absence of stimuli and inhibitors $\left(^{*}, P<0.05 ; * *, P<0.01\right.$ vs the first row in each column). 


\begin{tabular}{|l|c|c|}
\hline & $\begin{array}{c}\text { Vmax } \\
(\mathbf{n m o l e s} / \mathbf{m i n})\end{array}$ & $\begin{array}{c}\mathbf{K m} \\
(\mathbf{m M})\end{array}$ \\
\hline Basal uptake & 0.39 & 0.08 \\
\pm 0.04 & \pm 0.04 \\
\hline Insulin & 0.59 & 0.08 \\
$(\mathbf{1 0 0} \mathbf{n M})$ & $\pm 0.07^{*}$ & \pm 0.05 \\
\hline Olanzapine & 0.51 & 0.08 \\
$(\mathbf{2 0} \boldsymbol{\mu M})$ & $\pm 0.05^{*}$ & \pm 0.06 \\
\hline
\end{tabular}

Table 2. Effects of olanzapine $(20 \mu \mathrm{M})$ versus insulin $(100 \mathrm{nM})$ on the rate of glucose transport as a function of substrate concentration in C2C12 cells. The values for maximum transport velocity (Vmax) and the Michaelis-Menten constant (Km) were computed using nonlinear regression (GraphPad Prism software 3.0; *, P<0.05 vs basal uptake). 